\title{
Analyzing Spaces for Social Interaction in Coworking Space: A case study on Common Ground Damansara Heights
}

\author{
Cho Ken Ying, Filzani Illia Ibrahim, Zahari Zubir \\ School of Architecture Building and Design, Faculty of Innovation and Technology, \\ Taylor's University, Selangor \\ kenying1510@gmail.com, filzanillia@gmail.com,Zahari.Zubir@taylors.edu.my \\ $+60146729244$
}

\begin{abstract}
Coworking is defined as people work and share the same facilities; creating social interaction to form a community. Through literature publication in Asia, most of the studies are focusing on market value and revenue; lack study on social interaction topic. This study aims to analyse spaces for user social interaction in coworking space in Common Ground Damansara Heights. To achieve the aim, it identifies types of social interaction in coworking space. Site observation and data are analysed to determine the availability of spaces for social interaction. This conclusion informs suggestion to designers and academics on consideration in coworking spaces for user to socialise.
\end{abstract}

Keywords: Coworking; social interaction

eISSN: 2398-4287 @ 2020. The Authors. Published for AMER ABRA cE-Bs by e-International Publishing House, Ltd., UK. This is an open access article under the CC BYNC-ND license (http://creativecommons.org/licenses/by-nc-nd/4.0/). Peer-review under responsibility of AMER (Association of Malaysian Environment-Behaviour Researchers), ABRA (Association of Behavioural Researchers on Asians) and cE-Bs (Centre for Environment-Behaviour Studies), Faculty of Architecture, Planning \& Surveying, Universiti Teknologi MARA, Malaysia.

DOI: https://doi.org/10.21834/e-bpj.v5i13.2068

\subsection{Introduction}

This study of coworking literature will give an insight into the definition, growing trends of coworking, and thus identify the issues of current research. The new movements of 'coworking' emerging rapidly into local context in Malaysia since 2010; website such as www.coworker.com aid to facilitate coworkers locally and globally; to search for their best choice of coworking spaces before they visit.

Recent year there are news publication by 'The Edge Malaysia (2018) - Trends: Making space for work', 'New Straits Times (2018) - Demand for coworking and technology-related spaces will be trending this year', 'The Malaysian Reserve (2019) - Coworking spaces to alleviate burden of local businesses'; these are the facts that they are in trends and people are promoting nowadays (Fig. 1).

Besides, there are recent years publication from researcher in Asia which are summarised in Table 1; in Malaysia carried out by Kenanga (2018) "The rise of coworking spaces in Malaysia" to study about core factors of increasing popularity of coworking spaces; Malaysia by Aliff Yusri (2018) "Room To Grow: Coworking Spaces And Smes" to explore about current economics of coworking spaces; Malaysia by Lim (2018) "Curating Coworking Space as A Third Place" to study the concept and possibility of coworking space for interaction; Singapore by Tie (2018) "Coworking Space" to study about facts in Singapore on the growth of coworking spaces; China by Zhai (2017) "A study of the coworking operating model" to explore on optimal types of operating coworking spaces.

In conclusion, the study can be generalised that current state of documentation and research should put into considerations of more critical thinking on the social interaction between the community users in coworking space; thus, it can provide more understanding on the rise of diversity in coworking spaces.

eISSN: 2398-4287 @ 2020. The Authors. Published for AMER ABRA cE-Bs by e-International Publishing House, Ltd., UK. This is an open access article under the CC BYNC-ND license (http://creativecommons.org/licenses/by-nc-nd/4.0/). Peer-review under responsibility of AMER (Association of Malaysian Environment-Behaviour Researchers), ABRA (Association of Behavioural Researchers on Asians) and cE-Bs (Centre for Environment-Behaviour Studies), Faculty of Architecture, Planning \& Surveying, Universiti Teknologi MARA, Malaysia.

DOI: https://doi.org/10.21834/e-bpj.v5i13.2068 


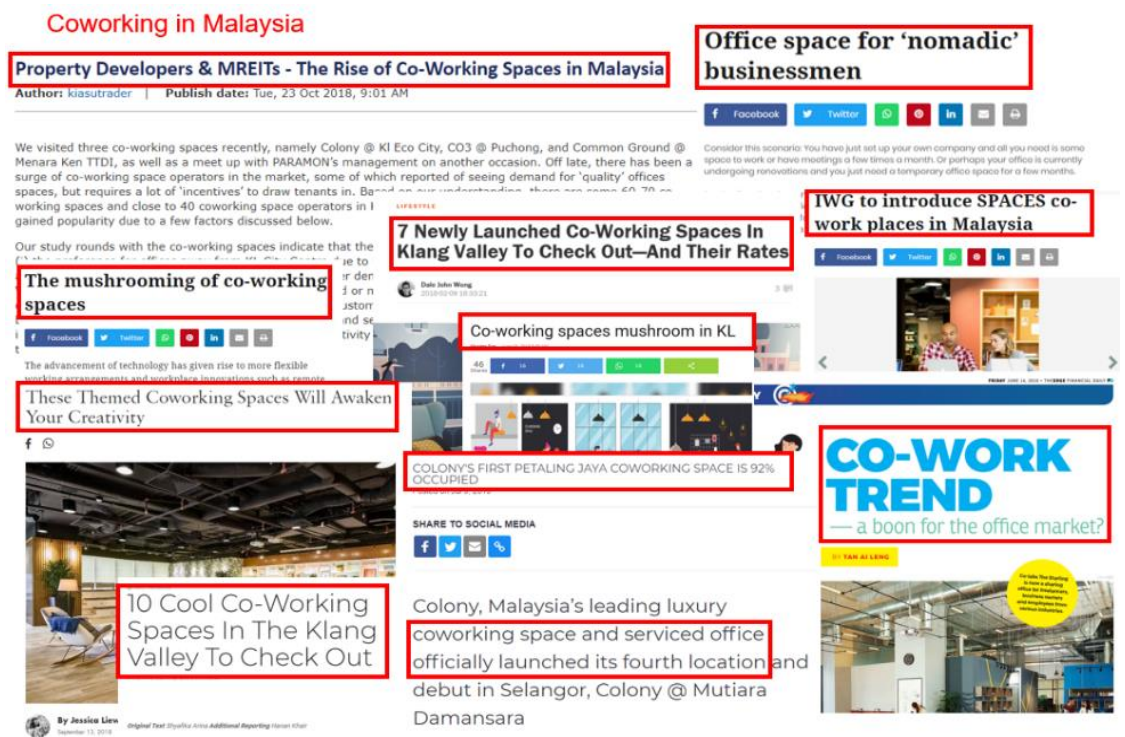

Fig. 1: Collage of recent years news publication of coworking in Malaysia (Source: Author, 2019)

Table 1. Recent years publication from researcher in Asia

\begin{tabular}{lcccl}
\hline \multicolumn{1}{c}{ Title } & $\begin{array}{c}\text { Year of } \\
\text { Publication }\end{array}$ & Author & Context & Description of study \\
\hline $\begin{array}{l}\text { The rise of coworking spaces in } \\
\text { Malaysia }\end{array}$ & 2018 & Kenanga & Malaysia & $\begin{array}{l}\text { Core factors of increasing popularity } \\
\text { of coworking spaces }\end{array}$ \\
\hline $\begin{array}{l}\text { Room To Grow: Co-Working } \\
\text { Spaces And Smes }\end{array}$ & 2018 & Aliff Yusri & Malaysia & $\begin{array}{l}\text { Current economics of coworking } \\
\text { spaces }\end{array}$ \\
\hline $\begin{array}{l}\text { Curating Coworking Space as A } \\
\text { Third Place }\end{array}$ & 2018 & Lim & Malaysia & $\begin{array}{l}\text { Concept and possibility of coworking } \\
\text { space for interaction }\end{array}$ \\
\hline $\begin{array}{l}\text { Coworking Space } \\
\text { A study of the coworking }\end{array}$ & 2018 & Tie & Singapore & $\begin{array}{l}\text { Facts in Singapore on the growth of } \\
\text { coworking spaces }\end{array}$ \\
\hline \begin{tabular}{l} 
operating model \\
\hline
\end{tabular} & 2017 & Zhai & China & $\begin{array}{l}\text { Optimal types of operating } \\
\text { coworking spaces }\end{array}$ \\
\hline
\end{tabular}

(Source: Author, 2019)

\subsection{Research Gap}

The lack of study to a deeper understanding of user social interaction in coworking spaces in Malaysia, this might be the key point to improve and expand better in coworking spaces in Malaysia. The review of literature points towards the following issues:

Literature leads a gap towards the reason of coworking arising popularity; which only focus on revenue and economic; but lack of deeper understanding of analysing user social interaction in coworking spaces in Klang Valley, Malaysia. (The Edge Malaysia, 2018; New Straits Times, 2018; The Malaysian Reserve, 2019; Lim, 2018; Kenanga, 2018; Aliff Yusri, 2018; Ondia et.al, 2018; Tie, 2018; Zhai, 2017; Frank, 2018).

\subsection{Aim}

The study aims to analyse spaces for user social interaction in coworking space in Common Ground Damansara Heights.

\subsection{Objective}

To achieve the aim, this study will be based on the objective to identify types of spaces for social interaction of coworking space.

\subsection{Literature Review}

\subsection{Definition of coworking}

Table 2 summarised a different definition of "coworking" by authors over the years. As defined by Fost (2008), he stated that the term 'coworking' indicate the practice of working individually in a shared environment, which differentiate with 'coworking', means working closely together on a piece of work (Gandini, 2015). Likewise, Frank (2018) interpreted coworking as space where people who are selfemployed to share facilities, thoughts and information within the same office. Besides, a study of collaborative production in Berlin by Lange (2011) showed that workers joined in attempting for own independence in collaborative networks in coworking spaces, which share the common values (Gandini, 2015).

Moriset (2013) defined it as workers' places to maximise chance and potential interaction with others. Foertsch (2014) further explained coworking space as a membership-based, integrative workspace for individuals and start-up companies; which provide 
community, business services, team up chances and a place to focus on work. Similarly, coworking spaces are defined by Capdevila (2015), as new kind of organisations, which people work according to the fundamental values to communicate with the community, areas incorporated with openness, accessibility and sustainability (Ivaldi, Pais \& Scaratti, 2018). This is agreed by Spinuzzi (2012), who defined coworking spaces as open-plan office environments with entrance fees where workers work with other professionals. As in 2019, coworking evolves to redefine the representation of working independently with the flexibility of working together, which share the common values (Coworking, 2019).

In conclusion, the definition of "coworking" is work together in a shared space, sharing the same facilities, either independently or as in a group of people; creating social interaction between users. Therefore, "social" is the keyword for this study. The rise of coworking trend in Malaysia leads to a need to analyse the application of original coworking design intention; which focus on the communityorientated workplace to promote social interaction.

Table 2. Chart showing definition of coworking by different authors over the years

\begin{tabular}{|c|c|c|}
\hline Year & Author & Definition of coworking space \\
\hline 2008 & Fost & Working individually in a shared environment \\
\hline 2011 & Lange & $\begin{array}{l}\text { Workers joined for own independence and share common } \\
\text { value }\end{array}$ \\
\hline 2012 & Spinuzzi & $\begin{array}{l}\text { Open-plan office environments with entrance fees where } \\
\text { workers work with other professionals }\end{array}$ \\
\hline 2013 & Moriset & $\begin{array}{l}\text { Workers' places to maximize chance and potential interaction } \\
\text { with others }\end{array}$ \\
\hline 2014 & Foertsh & Integrative workspace which provide community \\
\hline 2015 & Capdevila & $\begin{array}{l}\text { People work according to basis values to communicate with } \\
\text { community }\end{array}$ \\
\hline 2018 & Frank & People share facilities, thoughts and information in same office \\
\hline 2019 & Coworking & Working independently with flexibility and share common value \\
\hline \multicolumn{2}{|c|}{ Own definition } & $\begin{array}{l}\text { Work together in a common space, share same facilities, } \\
\text { creating social interaction between users. }\end{array}$ \\
\hline
\end{tabular}

\subsection{Definition of social interaction in coworking spaces}

Goffman (1955) defines communication as a process which people act and react to those who are around; it also can be described as the social exchange between two or more individuals (as cited by Cabral, 2016). At such, social interactions are beneficial to both parties as social support (Shinn et.al, 1984). Coworking spaces are a platform for people to interact and share knowledge. According to Parrino (2015), social interaction in coworking space usually stimulated by people who are facilitating social events there. The main idea is to focus on creating community and connects the coworkers who are working alone; to bring social dimension back to their working life (Garrett et al., 2017; Johns \& Gratton, 2013; Moriset, 2013; Hillman, 2008).

Coworking spaces always trademark themselves as 'membership community', which they had already highlighted on the spontaneous social interactions of its users as a core feature (Fost, 2008; Sundsted et al., 2009; Hunt, 2009; Botsman \& Rogers, 2011; Spinuzzi, 2012; Capdevila, 2013; Parrino, 2013; Kojo \& Nenonen, 2017; Liegl, 2014; Lumley, 2014; Bilandzic \& Froth, 2015; Gandini, 2015).

In general, social interaction can be defined as it happened in coworking is when there is two-person and above, greet and talk with each other; they will create the community social spark in between.

\subsection{Formal and informal social interaction in coworking spaces}

A coworking space always consists of formal and informal spaces incorporate with functional spaces elements; whereby each user in the social network serve as core connection in coworking space. Clean shared facilities which involved interaction are meeting rooms and collaborative spaces. The free shared facilities in coworking spaces are shared workspaces, networking events areas, coffee corners, kitchen, printer and copying area and lounges spaces; normally more interaction between users happens here (Perree et al., 2019). Similarity, Hua et al. (2010) stated that different types of communication would occur in different spaces based on the usage of the users. For example, meeting rooms are utilised for formal meetings and training. Meanwhile, the apparent type of informal interaction with happening in shared service areas such as printing zone or coffee corner.

According to Hua et al. (2010), the shared facilities spaces can be categorised based on the level of interaction as these spaces can be utilised as interaction for casual conversation or collaborative works. Architects and designers are encouraged to design activitiesorientated workplace with interactive space to create communities, foster interaction and facilitate collaboration; about mix different user group personality into one (Lim, 2018).

In short, the consideration to identify users for formal and informal interaction during space planning is essential as it might give an impact on user social interaction in coworking space. Spaces for formal interaction might need proper furniture layout planning as they are more to proper meeting where social interaction level is low. In opposite, spaces for informal interaction might allow for more flexible kind of layout planning and the social interaction level is high. This led a gap to the following topic on the relationship between the level of interaction and openness of space design in coworking space. 


\subsection{Levels of interaction and openness of coworking spaces}

The usage of different types of communication in coworking spaces must be understood to design a better area. Lim (2018) stated that the openness of each of the regions should be based on types and levels of user's interaction. Previous studies showed that coworkers prefer work environment with a combination of open and closed spaces for different kinds of activities as some too open-plan work environments might lead to noise, privacy and concentration problems (Kim \& de Dear, 2013; Perree, 2019). The proper design and allocation of interaction spaces will be beneficial in terms of privacy and comfortability of conversation.

Lim (2018) stated that the connectivity between each of the spaces in coworking spaces would trigger the opportunity of individuals to socialise with each other. The hybrid zone of designing the plan allows user to have more proximity while having privacy for a specific activity. Likewise, Hillman (2014) stated that coworking could be related to catalysing the social coordination in the community, it can connect to one of the most frequently cited from coworking.org (2019): "Coworking spaces are about community-building and sustainability. Participants agree to uphold the values set forth by the movement's founders, as well as interact and share. We are about creating better places to work and as a result, a better way to work."

In conclusion, if space is having high levels of social interaction between users, the areas should be as open as a feeling to welcome and invite users into it. At such, it can be assumed that spaces involved more private interaction which consisted of 2 to 3 people may require more enclosed spaces for privacy purpose.

\subsection{Research Method}

\subsection{Study Area - Common Ground Damansara Heights}

A case study will be carried out in one of well-known Malaysia's largest coworking space operator for coworking spaces - Common Ground Damansara Heights. It is situated at the penthouse of Wisma UOA Damansara II, Damansara Heights; which is close to surrounding business districts like Bangsar, KL Sentral, Petaling Jaya and Kuala Lumpur city (Fig. 2). Their slogan is "Ambition Lives Here" and their main ideas are to focus on community and lifestyle. At such, the reflectance of the coworking spaces design will be beneficial to this study.

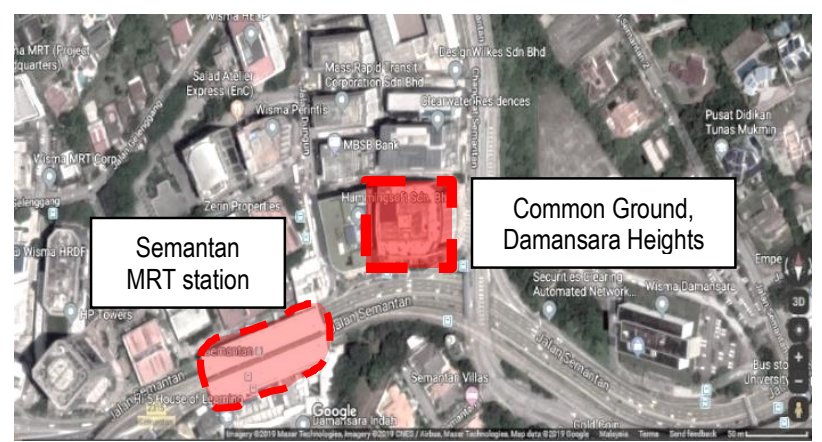

Fig. 2: Location Plan of Common Ground Damansara Heights (Source: Google, 2019)

\subsection{Data Collection - Observation}

Due to limitation of time constraint and availability of coworkers on-site during the year-end holiday season, a one-day observation method is utilised for data collection in Common Ground Damansara Heights. Table 3 indicated structured observation and list of questions to staff in Common Ground. Structured observation is to identify the availability of spaces designed in this coworking space, conversation sound at each space, occupancy at each space, and interaction between members at each space. Later, the spaces are observed and categorized into formal (members have collaborative works, meeting or training) or informal (members have coffee talk or casual conversation) social interaction spaces which are analysed based on the usage of users on site. Data collected are documented in photography and field notes. The data is enhanced by having a short conversation with staff in Common Ground and documented in field notes.

Table 3. Table showing structured observation and list of questions to staff during site visit.

\begin{tabular}{|l|l|}
\hline Structured Observation & List of questions to staff \\
- What are the available spaces designed? & - What is the purpose of each spaces? \\
- Is each space very quiet or noisy? & - Is everyone allowed to enter all the spaces here? \\
- Are all the spaces fully occupied? & - How frequent is event space being utilised? \\
- Do members interact with each other at each space? & - What kind of activities to be held for the members? \\
\hline
\end{tabular}

(Source: Author, 2019)

\subsection{Data Analysis - Descriptive analysis}

Descriptive analysis is utilised to analyse the first-hand on-site observation data (Dhand, 2019). It gives an idea on the first-hand data on the variable (structured observation and list of questions to staff) which is listed in Table 3. Later, the combination of variables from first-hand data are analysed through sorting of spaces into formal (members have collaborative works, meeting or training) and informal (members have coffee talk or casual conversation) social interaction spaces. It will give an insight into the availability of different types 
of spaces for social interaction in Common Ground such as available public spaces for social interaction; available spaces for Common Ground members to networking and informal social interaction; available spaces for Common Ground members to work and collaborate.

\subsection{Findings}

Fig. 3 show floor layout zoning designed in Common Ground Damansara Heights. The zonings are categorized into available public spaces for social interaction; available spaces for Common Ground members to networking and informal social interaction; available spaces for Common Ground members to work and collaborate.

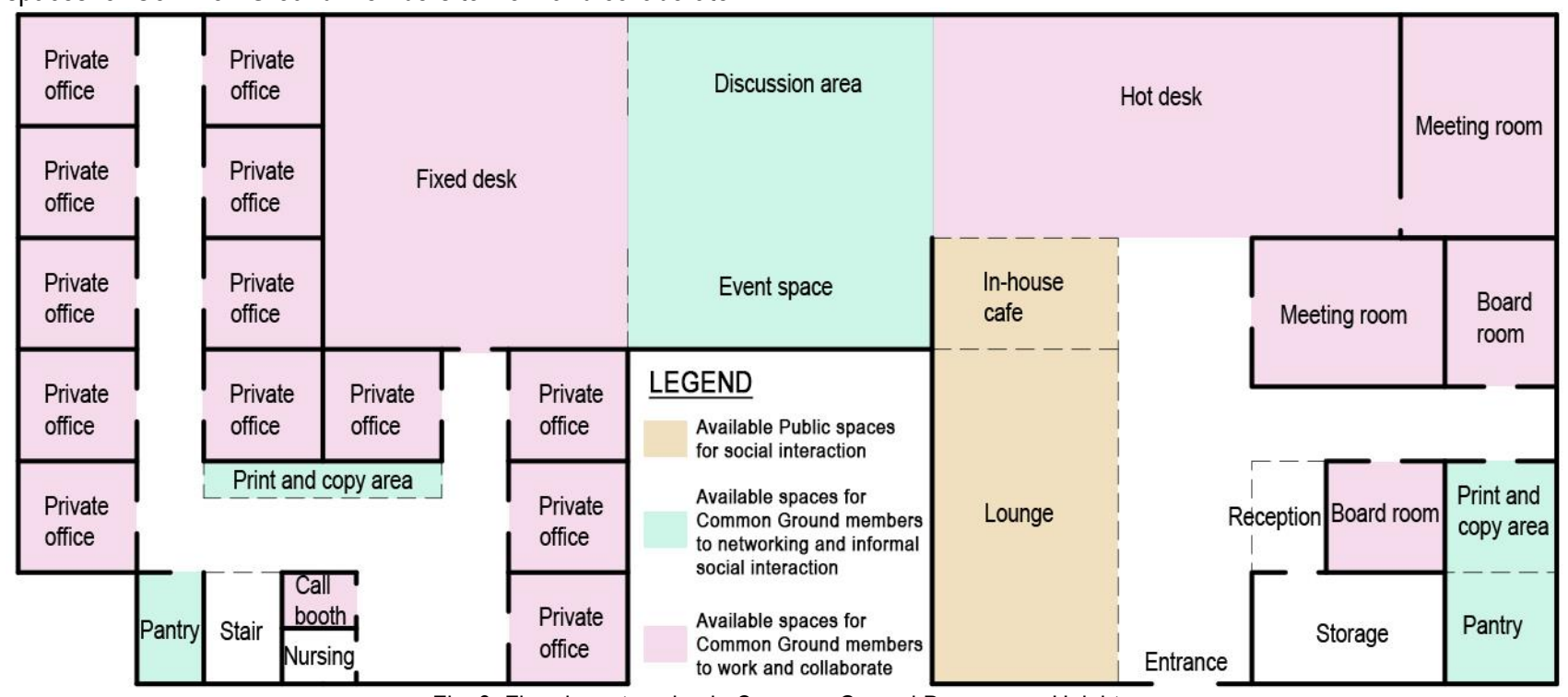

Fig. 3. Floor layout zoning in Common Ground Damansara Heights.

(Source: Author, 2019)

\subsection{Available Public spaces for social interaction}

There is a lounge to serve as waiting area for the public as people can have their orders from cafe. Also, the in-house cafe which attached to coworking spaces allows people to have their meals and drinks for social.

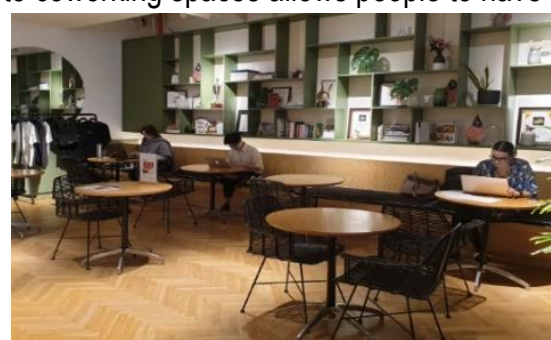

(a)

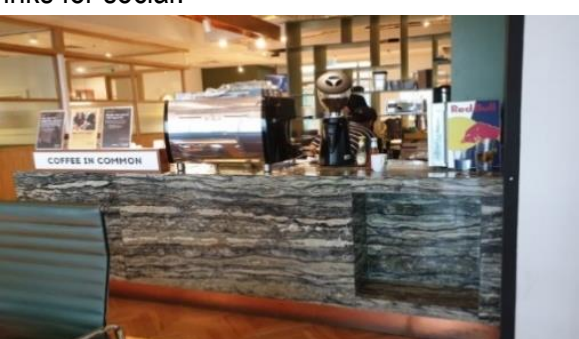

(b)

Fig. 4. (a) Lounge; (b) In-house cafe. (Source: Author, 2019)

4.2 Available spaces for Common Ground members to networking and informal social interaction

Based on the conversation, averagely there are 3 events in a week which incorporate talks, seminars, networking activities will be held here at the event spaces. The discussion area is designed as informal spaces for coworkers to have the conversation, relax or chit chat.

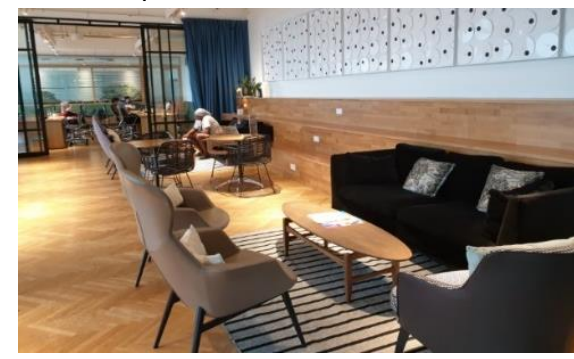

(a)

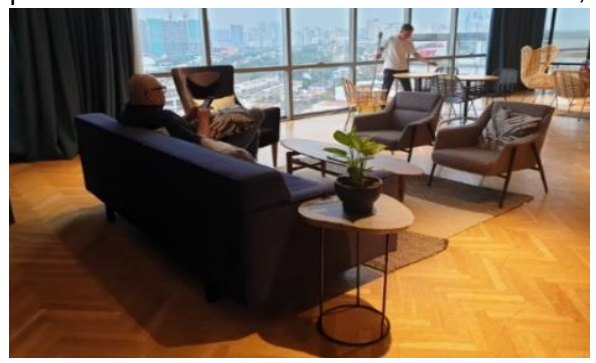

(b)

Fig. 5. (a) Event space; (b) Discussion area. (Source: Author, 2019) 
Few spots of print and copy area available to share among all coworkers. Sometimes, informal social interaction happens here. The pantry served as familiar drink corners in the coworking spaces, which allow users to chit chat while making their drinks.

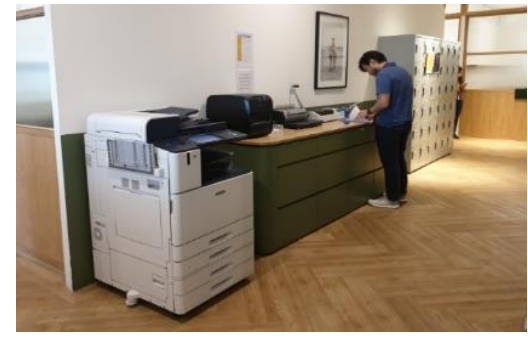

(a)

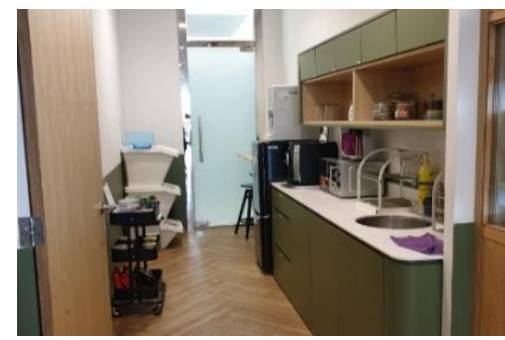

(b)

Fig. 6. (a) Print and copy area; (b) Pantry. (Source: Author, 2019)

\subsection{Available spaces for Common Ground members to work and collaborate}

There are 80 hot desks which are un-reserved desks for coworkers to bring their own computer devices and can select any of the seats for their works. The open plan allows coworkers to interact easily. There are 30 reserved fixed desks for designated coworkers, and they have drawers to store their items here. The free program will enable coworkers to interact easily.

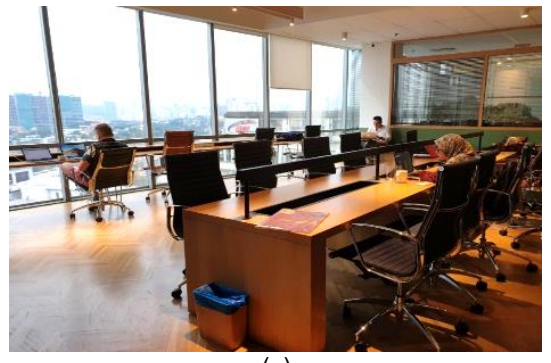

(a)

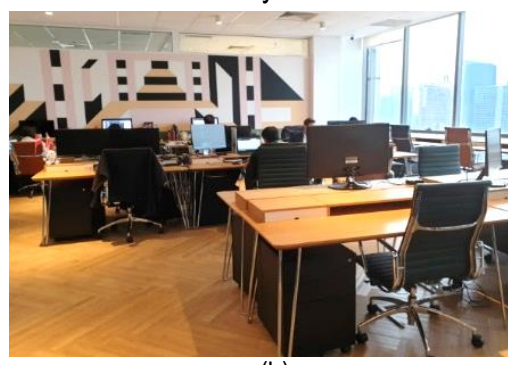

(b)

Fig. 7. (a) Hot desks; (b) Fixed desk. (Source: Author, 2019)

Private offices designated for coworkers who need more privacy on doing their works. Less interaction happens here. Call booth as private areas which are enclosed for users to have call conversation.

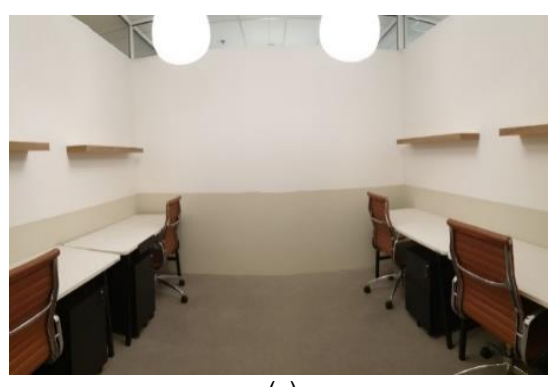

(a)

Fig. 8. (a) Private office; (b) Call booth.

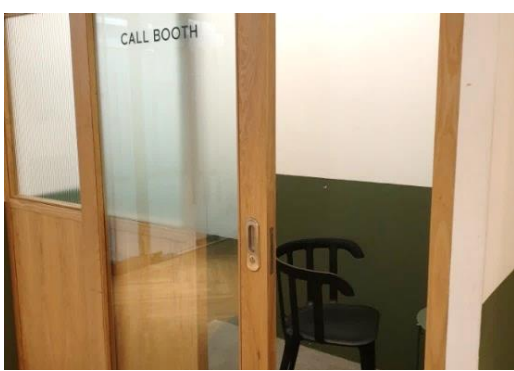

(b) (Source: Author, 2019)

Proper meeting rooms with fixed furniture allowing users to have collaborative activities. The smaller scale of board room areas with inspiring interior design for coworkers will enable people to interact.

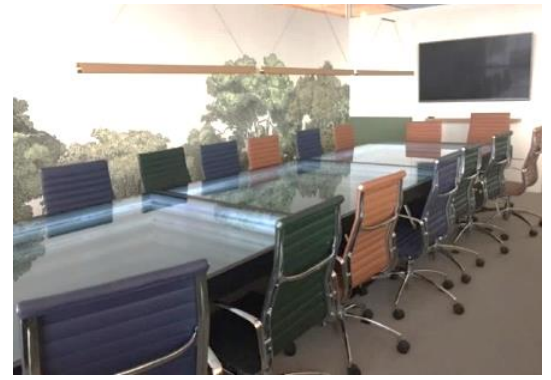

(a)

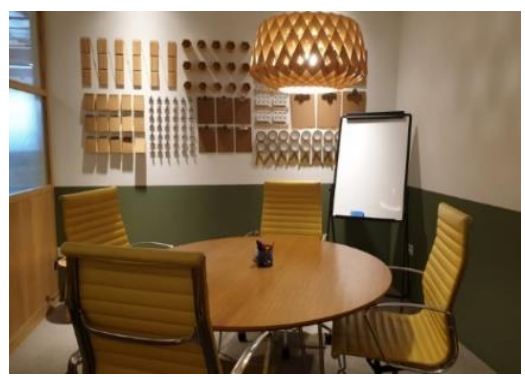

(b)

Fig. 9. (a) Meeting room; (b) Board room. (Source: Author, 2019) 


\subsection{Discussion}

5.1 Formal and informal social interaction in coworking spaces

In general, it can be observed that most of the areas in Common Ground Damansara Heights are quite functional as they served for more than one purpose for each space. Formal and informal social interaction can happen with the useful use of the users at each corner of the coworking spaces. As refer to Perree et al. (2019), more interaction will occur in shared workspaces, event area, pantry area, printer and copy area and lounge area; this can be related to Common Ground as most of the spaces are quite open for public, and every coworking members can access easily; to improve the social interaction in between. Besides, refers to Hua (2010) who stated different types of communication happen based on usage of users; this can be related to Common Ground as positive elements; based on-site observation, the usage of rooms such as meeting room and board rooms are flexible based on users; they can change the function of the places and have either formal or informal social interaction in it.

The design of each space in Common Ground did consider for social interaction of users; this complied to Hua (2010) statement which encourages more activities-orientated working area with interactive spaces to foster communication. With event spaces and activities to be held three times a week, it can significantly promote and connect coworkers into one.

In short, Common Ground has many small spaces. Still, each of them can function individually, or can be combined to become more flexible for the users to socialise, have a coffee talk, collaborate, have a discussion or some other conversation. A survey on the users can be carried out for future implication to know more about their thoughts on social interaction.

\subsection{Levels of interaction and openness of coworking spaces}

The common spaces in Common Ground such as workspace, lounge, event spaces are mostly open and visible by each of the members. With the combination of some enclosed areas such as meeting room, board rooms, private office and call booths, it did consider for some coworkers concern by the previous study which emphasises on preference to a combination of open and closed spaces. Based on Lim (2018), working environment with the fully open plan may distract the users through noise and privacy; in Common Ground, the users are allowed to select their enclosure of spaces based on their usage freely. This is beneficial in terms of confidentiality and comfortability of each user in the areas during the conversation.

The openness of most spaces may have the concern to privacy and noise issue, yet most of the time users will feel more comfortable walking and chatting freely with less personality constrained. Lastly, refers to Hillman (2014), a better place to work and interact can significantly enhance the values of the users in coworking spaces. The feeling of walking into each area in Common Ground may lead users to more interaction as with the existence of lounge and café; it can promote better visual contact and reduce the proximity of social distance between users.

\subsection{Conclusion \& Recommendations}

Site observation and analysis indicated the existence of different types of spaces in Common Ground Damansara Heights to cater to various function or purpose of the users. The consideration of formal and informal social interaction which related to openness design of the spaces in Common Ground enhance the value of the coworking spaces. This combination of open and enclosed space allows users to select freely where they want to be; therefore, added value for people who work there. This data may help academics and designers to alert on more concern when providing spaces for coworking spaces as it needs to be tie back to the original value of coworking which is to emphasise on the word 'social'.

Future research implication can be enhanced by doing questionnaire survey to study about the user perception and preferences on social interaction in coworking space; analyse factors which affect social interaction, and analyse the outcome of social interaction; thus, suggest ideas to promote user social interaction in coworking space.

\section{Acknowledgement}

We are here to express utmost gratitude to the individuals in Common Ground Damansara Heights who have extended their assistance throughout the construction of this paper.

\section{References}

Aliff Yusri. (2018). Room to Grow: Co-Working Spaces and SMEs.

Bilandzic, M., \& Foth, M. (2015). Designing hubs for connected learning: Social, spatial and technological insights from coworking, hackerpaces and meetup Groups.

Botsman, R., \& Rogers, R. (2011). What's Mine Is Yours: How Collaborative Consumption Is Changing the Way We Live. 2nd edition. Londres: Harper Collins.

Cabral, V. \& Willem, V. W. (2016). Coworking: An analysis of coworking strategies for interaction and innovation. doi: 10.13140/RG.2.1.4404.5208

Capdevila, I. (2015). Co-working spaces and the localised dynamics of innova-tion in Barcelona. International Journal of Innovation Management, 19(3) https://doi.org/10.1142/S1363919615400046

Common Ground. (2019). Retrieved from https://www.commonground.work/ 
Coworking.org (2019). Retrieved from http://coworking.com/

Dhand, N. (2019). Descriptive Analysis: Take it easy. Retrieved from http://statulator.com/blog/descriptive-analysis-take-it-easy/

Fost, D. (2008) 'They're working on their own, just side by side'. New York Times, 20 February.

Frank, K. (2018). Cotra-working: The office of the future?

Gandini, A. (2015). The rise of coworking spaces: A literature review. volume 15(1): 193-205. ISSN 1473-2866

Goffman, E. (1955). On facework: an analysis of ritual elements in social interaction. Psychiatry: Journal for the Study of Interpersonal Processes 18: 213-231.

Hillman, A. (2008). 6 reasons to start coworking. Retrieved from http://mashable.com/2008/11/07/reasons-to-start-coworking/\#0RcXbSvNdEqQ.

Hillman, A. (2014). To build a strong community, stop "community managing", be a Tummler instead.

Hua, Y., Loftness, V., Kraut, R., \& Powell, K. M. (2010). Workplace collaborative space layout typology and occupant perception of collaboration environment. Environment and Planning B: Planning and Design, 37, 429-448.

Hunt, T. (2009). The whuffie factor: Using the power of social networks to build your business. Crown Pub ILO/Hart Publishing.

Ivaldi, S., Pais, I., \& Scaratti, G. (2018). Coworking(s) in the Plural: Coworking Spaces and New Ways of Managing. DOI: 10.1007/978-3-319-66038-7_11

Johns, T., \& Gratton, L. (2013). The third wave of virtual work: Knowledge workers are now untethered, able to perform tasks anywhere at any time. What do the best of them want from your organization. Harvard Business Review, January-February, 1-9.

Kim, J., \& de Dear, R. (2013). Workspace satisfaction: The privacy-communication trade-off in open-plan offices. Journal of Environmental Psychology. doi:10.1016/j.jenvp.2013.06.007

Kojo, I., \& Nenonen, S. (2017). Evolution of co-working places: drivers and possibilities. Intelligent buildings international, 9(3), $164-175$.

Liegl, M. (2014). Nomadicity and the care of place—on the aesthetic and affective organization of space in freelance creative work. Computer Supported Cooperative Work (CSCW), 23(2), 163-183.

Lim, J.Y. (2018). Curating Coworking Space as A Third Place. https://issuu.com/joanna.lim.yin/docs/curating_coworking_space_as_a_third

Lumley, R. M. (2014). A coworking project in the campus library: supporting and modeling entrepreneurial activity in the academic library. New Review of Academic Librarianship, 20(1), 49-65.

Moriset, B. (2013). Building new places of the creative economy. The rise of coworking spaces

Ondia, E. P., Hengrasmee, S., \& Chansomsak, S. (2018). Spatial Configuration and Users' Behavior in Co-working Spaces. Ybl Journal of Built Environment, 6(1), doi:10.2478/jbe-2018-0002

Parrino, L. (2015). Coworking: Assessing the role of proximity knowledge exchange. Knowledge Management Research and Practice, 13, $261-271$.

Perree, M. W., Koevering, J., Meulenbroek, R. A., \& Arentze, T. (2019). Analysing user preferences for co-working space characteristics. Building Research \& Information, 47(5), 534-548, doi: 10.1080/09613218.2018.1463750

Shinn, M. , Lehmann, S., \& Wong, N. W. (1984). Social interaction and social support. J. Soc.Issues 40, 55-76. doi:10.1111/j.1540-4560.1984.tb01107.x

Spinuzzi, C. (2012). Working alone together coworking as emergent collaborative activity. Journal of Business and Technical Communication,26(4), 399-441.

Spreitzer, G. et.al. (2015). Why People Thrive in Coworking Spaces. Retrieved from https://hbr.org/2015/05/why-people-thrive-in-coworking-spaces

Sundsted, T., Jones, D., \& Bacigalupo, T. (2009). I'm outta here: How coworking is making the office obsolete.

Tie, E. (2018). Coworking Spaces. Retrieved from www.etcsea.com 